\title{
Penggunaan Probiotik pada Budidaya Ikan Lele Sangkuring (Clarias sp.) di Drum Plastik di Desa Arisan Jaya, Ogan Ilir, Sumatera Selatan
}

\author{
The Utilizing of Probiotics for Catfish Sangkuriang (Clarias sp.) Cultivation in Plastic \\ Pond at Arisan Jaya Village Ogan Ilir, South Sumatera \\ Ade Dwi Sasanti ${ }^{1}$, Septika Putri Anggraini ${ }^{2 *}$ \\ ${ }^{1}$ Program Studi Budidaya Perairan, Fakultas Pertanian, Universitas Sriwijaya, \\ Indralaya 30662 \\ ${ }^{2}$ Program Studi Pengelolaan Lingkungan, Program Pascasarjana Universitas Sriwijaya, Palembang 30139 \\ *Penulis untuk korespondensi: septikaputri@ student.pps.unsri.ac.id
}

(diterima 23 April 2019,disetujui 11 Juli 2019)

Sitasi: Sasanti AD, Anggraini SP. 2019. The utilizing of probiotics for catfish sangkuriang (Clarias sp.) cultivation in plastic pond at arisan jaya village Ogan Ilir, South Sumatra. Jurnal Lahan Suboptimal: Journal of Suboptimal Lands. 8(2): 134-140.

\begin{abstract}
The research was to provide information to farmers on the use probiotics on catfish (Clarias sp.). The used of probiotics aimed to maintain balance pathogenic microbes and suppress activity in the digestive tract, and the environmental biodegradation waters through the process. This study aimed to compare of field Practice is to provide information to the people about the utilizing of probiotics for catfish (Clarias sp.) cultivation a plastic drums at Arisan Jaya village Ogan Ilir. The research used two plastic drum media as a catfish maintenance container, the first maintenance container there was no addition of probiotics, while in the second maintenance container there was the addition of probiotics. The parameters were observed in this study were absolute weight growth, absolute the length growth, survival, and water quality. The result of this research showed that growth of catfish cultivation in plastic pond with length of $3,51 \mathrm{~cm}$ and weight of catfish the used probiotics of $17,15 \mathrm{~g}$ was higher than the growth length of $2,46 \mathrm{~cm}$ and weight of catfish were not using probiotics of $12,03 \mathrm{~g}$. The survival rate of the catfish utilizing of probiotics cultivation in plastic drums with the use probiotics and not use probiotics was $100 \%$.
\end{abstract}

Keywords: arisan jaya, growth, probiotics, survival rate

\begin{abstract}
ABSTRAK
Penelitian ini adalah untuk memberikan informasi kepada para petani mengenai penggunaan probiotik pada ikan lele sangkuriang (Clarias sp.). Penggunaan probiotik bertujuan untuk menjaga keseimbangan mikroba dan menekan aktifitas patogen dalam saluran pencernaan, serta perbaikan lingkungan perairan melalui proses biodegredasi. Tujuan dari penelitian ini adalah untuk memberikan informasi kepada para petani mengenai penggunaan probiotik pada ikan lele sangkuriang (Clarias sp.) yang dipelihara di drum plastik di Desa Arisan Jaya, Ogan Ilir. Penelitian ini menggunakan dua media drum plastik sebagai wadah pemeliharaan ikan lele, pada wadah pemeliharaan pertama tidak terdapat penambahan probiotik, sedangkan pada wadah pemeliharaan kedua terdapat penambahan probiotik. Parameter yang diamati dalam penelitian ini adalah pertumbuhan
\end{abstract}


bobot mutlak, pertumbuhan panjang mutlak, kelangsungan hidup, serta kualitas air. Hasil dari penelitian ini menunjukkan bahwa lele sangkuriang yang dipelihara di drum plastik menghasilkan pertumbuhan panjang mutlak sebesar 3,51 dan bobot mutlak ikan lele sangkuriang (Clarias sp.) sebesar 17,15 g yang menggunakan probiotik (Wadah I) lebih tinggi daripada pertumbuhan panjang mutlak ikan lele yang tidak menggunakan probiotik sebesar 2,46 dan bobot mutlak ikan lele sangkuriang (Clarias sp.) yang tidak menggunakan probiotik sebesar 12,03 (Wadah II). Selanjutnya kelangsungan hidup pada budidaya ikan lele sangkuriang di drum plastik ini yang menggunakan probiotik maupun tidak menggunakan probiotik sebesar $100 \%$.

Kata kunci: arisan jaya, drum plastik, probiotik, pertumbuhan, kelangsungan hidup

\section{PENDAHULUAN}

Berdasarkan data sasaran peningkatan produksi perikanan budidaya tahun 20152019, Ikan lele merupakan salah satu komoditas budidaya ikan air tawar unggulan di Indonesia. Komoditas ikan lele menunjukkan peningkatan produksi setiap tahunnya (Perikanan, 2016).

Produksi ikan lele di Sumatera Selatan pada tahun 2012 sebesar 23.941 ton sedangkan pada tahun 2013 mengalami peningkatan produksi mencapai 24.328 ton. Hal ini menunjukkan kebutuhan ikan lele di Sumatera Selatan terus mengalami peningkatan. Peningkatan kegiatan budidaya akan meningkatkan produksi, sementara intensifikasi budidaya disebabkan oleh hal lain, seperti efisiensi, optimasi yang disebabkan persaingan dan margin usaha yang tipis, pengenalan teknologi. Meningkatnya kegiatan budidaya menyebabkan para petani mulai melakukan kegiatan budidaya ikan lele secara intensif untuk memenuhi kebutuhan pasar.

Terpal merupakan bahan plastik kedap air, dimana sifat itu yang membuatnya berguna sebagai lapisan penahan air di kolam. Kolam terpal pada umumnya sudah biasa dipakai peternak ikan hias, tetapi pada peternak ikan konsumsi sangat jarang. Keunggulan penggunaan kolam dari terpal antara lain kolam terpal mudah dibuat, suhu kolam lebih stabil dibandingkan kolam semen (Rosalina, 2014). Selain biaya yang dikeluarkan lebih kecil dari media lainnya, keterbatasan lahan juga tidak menjadi masalah, kolam dapat dipindahkan sesuai keinginan, ikan mudah dikontrol, kondisi air relatif lebih bersih, yang terpenting menghemat biaya dan juga budidaya ikan lele bisa diterapkan dikolam terpal ini.

Intensifikasi usaha pada budidaya ikan biasanya dilakukan pada upaya mengurangi dan mengefisiensikan penggunaan pakan. Pakan merupakan komponen terbesar dalam proses budidaya ikan. Menurut (Sahwan, 2004), pakan merupakan salah satu faktor terpenting pada proses budidaya yang akan berpengaruh terhadap pertumbuhan dan kelangsungan hidup ikan yang akan dibudidayakan. Pakan yang biasanya digunakan pada suatu budidaya ikan membutuhkan sekitar $60-70 \%$ dari biaya produksi yang dikeluarkan oleh pembudidaya. Kandungan nutrisi serta tingkat kecernaan pakan sangat dipengaruhi oleh pemanfataan kualitas pakan. Pakan yang berkualitas memiliki peran sebagai sumber energi utama yang juga diharapkan mampu meningkatkan daya cerna ikan sehingga dapat meningkatkan pertumbuhan ikan menjadi optimum (Ahmadi dan Iskandar, 2012).

Pemberian organisme probiotik dalam akuakultur dapat diberikan melalui pakan, maupun melalui penyemprotan probiotik pada pakan yang berpengaruh pada kecepatan fermentasi pakan tersebut dalam saluran pencernaan, sehingga membantu proses pencernaan dan penyerapan sari makanan (Irianto, 2007). Pemberian bakteri probiotik melalui pakan dilakukan bertujuan agar dapat mendegradasi protein, lemak maupun karbohidrat dalam tubuh ikan. Selain itu, pemberian bakteri dalam pakan juga diharapkan dapat masuk dalam saluran pencernaan ikan sehingga dapat 
memperbaiki kemampuan ikan dalam mencerna pakan. (Sunarma, 2004).

Pada penelitian ini pemberian pakan pada budidaya ikan lele sangkuriang (Clarias sp.) dilakukan dengan penggunaan probiotik yang dapat diaplikasikan melalui pakan dengan cara penyemprotan dan juga dapat melalui perendaman ke air. Tujuan dari penelitian ini adalah untuk memberikan informasi kepada para petani mengenai penggunaan probiotik pada ikan lele sangkuriang (Clarias sp.) yang dipelihara di drum plastik.

\section{BAHAN DAN METODE}

Penelitian dilaksanakan di Desa Arisan Jaya, Kecamatan Pemulutan Barat, Kabupaten Ogan Ilir Provinsi Sumatera Selatan pada bulan Desember 2015 sampai Januari 2016. Analisis kualitas air dilakukan di Balai Teknik Kesehatan Lingkungan dan Pengendalian Penyakit Palembang. Penelitian ini dilakukan pada dua wadah drum plastik yang diletakkan di pekarangan rumah masyarakat yang airnya bersumber dari lahan rawa lebak didepan rumah masyarakat.

\section{Rancangan Percobaan}

Penelitian ini menggunakan dua media drum plastik sebagai wadah pemeliharaan ikan lele, pada wadah pemeliharaan pertama tidak terdapat penambahan probiotik, sedangkan pada wadah pemeliharaan kedua terdapat penambahan probiotik. Tiap wadah pemeliharaan terdapat 150 ekor ikan lele. Sampling data pertumbuhan bobot dan panjang ikan dilakukan pada awal dan akhir pemeliharaan. Parameter yang diamati meliputi: pertumbuhan panjang ikan, pertumbuhan bobot ikan, kelangsungan hidup dan kualitas air (suhu, pH, DO (Disolved Oksigen), dan amonia).

\section{Cara Kerja}

\section{Persiapan Wadah Pemeliharaan Ikan}

Wadah yang digunakan dalam praktek lapangan ini adalah drum plastik berukuran
$110 \mathrm{~cm} \times 75 \mathrm{~cm} \times 64 \mathrm{~cm}$ sebanyak 1 buah. Sebelum digunakan drum plastik dicuci hingga bersih dan diisi air dengan ketinggian $180 \mathrm{~cm}$. Ikan lele sangkuriang yang digunakan memiliki panjang $12-14 \mathrm{~cm}$ dan bobot 19-21 g. Drum plastik diisi ikan lele sangkuriang sebanyak 75 ekor.

\section{Pemberian Probiotik}

Pakan yang digunakan adalah pakan komersil yang diberi probiotik $\mathrm{EM}_{4}$. Pencampuran probiotik $\mathrm{EM}_{4}$ ke dalam pakan dengan cara penyemprotan sebagai berikut : probiotik komersil sebanyak $6 \mathrm{ml}$ ditambahkan $50 \mathrm{ml}$ akuades dan $10 \mathrm{~g}$ gula pasir dicampurkan hingga homogen. Setelah semua bahan homogen lalu disemprotkan kedalam 100 g pakan secara merata (sesuai dengan takaran label probiotik komersil). Kemudian pakan berprobiotik tersebut lalu disimpan.

\section{Penebaran Ikan Ukuran 12-14 cm}

Sebelum ditebar, dilakukan pengukuran bobot ikan uji menggunakan timbangan digital dan panjang total menggunakan penggaris. Benih ikan lele ditebar dalam drum plastik. Penebaran ikan dilakukan pada sore hari.

\section{Pemeliharaan}

Pemeliharaan ikan dilakukan selama 30 hari. Selama pemeliharaan, ikan diberikan pakan dengan kandungan protein sebesar $33 \%$ secara at satiation. Frekuensi pemberian pakan adalah 3 kali sehari, yaitu pada pukul 08.00, 13.00, dan 16.00 WIB.

\section{Pengambilan Data \\ Pertumbuhan Bobot Mutlak}

Pertumbuhan bobot mutlak ikan lele sangkuriang selama pemeliharaan dihitung dengan menggunakan rumus (Effendie, 2002 ) adalah sebagai berikut:

$$
\mathrm{W}=\mathrm{Wt}-\mathrm{Wo}_{\mathrm{o}}
$$

Keterangan :

$\mathrm{W}=$ Pertumbuhan mutlak ikan yang dipelihara $(\mathrm{g})$ 
$\mathrm{Wt}=$ Berat ikan pada akhir pemeliharaan $(\mathrm{g})$ $\mathrm{Wo}=$ Berat ikan pada awal pemeliharaan (g)

\section{Pertumbuhan Panjang Mutlak}

Pertumbuhan panjang mutlak ikan lele sangkuriang selama pemeliharaan dihitung dengan menggunakan rumus (Effendie, 2002) adalah sebagai berikut:

$\mathrm{L}=\mathrm{Lt}-\mathrm{Lo}$

Keterangan :

$\mathrm{L}=$ Pertumbuhan panjang mutlak ikan yang dipelihara $(\mathrm{cm})$

$\mathrm{Lt}=$ Panjang ikan pada akhir pemeliaraan (cm)

Lo $=$ Panjang ikan pada awal pemeliharaan (cm)

\section{Kelangsungan Hidup}

Persentase kelangsungan hidup ikan lele dapat dihitung dengan menggunakan rumus (Effendie, 2002), adalah sebagai berikut:

$\mathrm{SR}=\frac{\mathrm{Nt}}{\mathrm{No}} \times 100 \%$

Keterangan :

$\mathrm{SR}=$ Kelangsungan hidup $(\%)$

$\mathrm{Nt}=$ Jumlah ikan yang hidup pada akhir pemelihaaraan (ekor)

No = Jumlah ikan pada awal pemeliharaan (ekor)

\section{Kualitas Air}

Parameter fisika-kimia air yang diukur selama penelitian adalah $\mathrm{pH}$, suhu, dan oksigen terlarut. Pengukuran dilakukan pada awal dan akhir pemeliharaan.

\section{HASIL DAN PEMBAHASAN}

\section{Pertumbuhan Panjang Mutlak dan Pertumbuhan Bobot Mutlak}

Berdasarkan hasil penelitian yang telah dilakukan didapat data pertumbuhan panjang mutlak (Gambar 1) dan pertumbuhan bobot mutlak ikan lele sangkuriang (Gambar 2). Berdasarkan hasil pengukuran panjang mutlak ikan lele sangkuriang pada wadah pemeliharaan drum plastik (Wadah I) yang diberi probiotik sebesar $3,51 \mathrm{~cm}$ sedangkan pada wadah pemeliharaan (Wadah II) panjang mutlak ikan lele sebesar 2,46 cm, sedangkan bobot mutlak pada (Wadah I) yang diberi probiotik didapat sebesar 17,15 g dan pada wadah pemeliharaan (Wadah II) sebesar 12,03 g.

Menurut Widodo dan Handajani (2010), menyatakan bahwa pertumbuhan sebagai pertambahan dalam volume dan berat dalam waktu tertentu. (Mudjiman, 2009), menyatakan bahwa faktor yang mempengaruhi pertumbuhan ikan dapat digolongkan menjadi dua yaitu faktor internal dan eksternal. Faktor internal merupakan faktor yang berhubungan dengan ikan itu sendiri seperti umur, dan sifat genetik ikan yang meliputi keturunan, kemampuan untuk memanfaatkan makanan dan ketahanan terhadap penyakit. Faktor eksternal merupakan faktor yang berkaitan dengan lingkungan tempat hidup ikan yangmeliputi sifat fisika dan kimia air, ruang gerak dan wadah pemeliharan.

Pertumbuhan panjang ikan dipengaruhi oleh genetika dari masing-masing individu dan juga asupan protein dari pakan (Esriyani, 2013). Untuk membantu pemanfaatan protein yang terkandung didalam pakan dibutuhkan bantuan mikrooraganisme proteolik yang dapat memecah protein menjadi polipeptida, oligopeptida dan asam amino yang bisa dimanfaatkan langsung oleh tubuh ikan untuk membantu pertumbuhannya (Pertiwi, 2014). Pertumbuhan ikan lele sangkuriang disebabkan oleh beberapa faktor terutama adanya pasokan energi dari pakan.

Penggunaan probiotik pada budidaya ikan lele sangkuriang menunjukkan adanya perbedaan disetiap wadah pemeliharaan (Wadah I) dengan penambahan bobot yang lebih baik dari pada wadah pemeliharaan yang tidak menggunakan probiotik (Wadah II). Tabel 1 menunjukkan pertumbuhan tertinggi didapat pada penggunaan probiotik. Pertumbuhan ikan lele sangkuriang disebabkan oleh beberapa 
faktor terutama adanya pasokan energi dari pakan. Kelebihan energi yang dibutuhkan untuk pemeliharaan dan aktifitas tubuh dimanfaatkan untuk pertumbuhan.

Hal tersebut dikarenakan penggunaan bakteri probiotik melalui pakan dapat

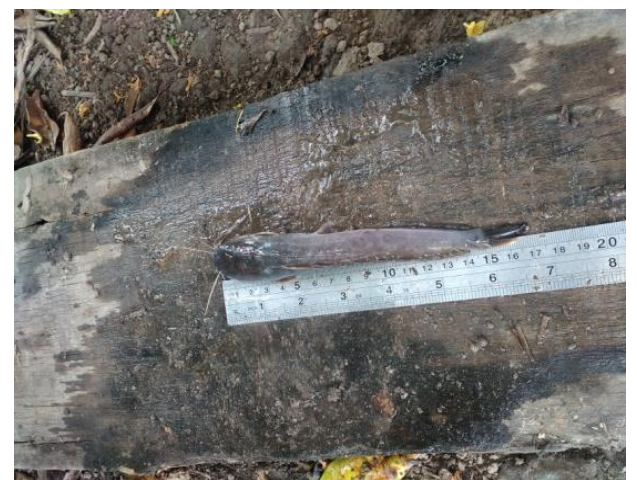

Gambar 1. Pengukuran panjang ikan lele memutus rantai polipeptida pada ketiga bahan tersebut saat masih dalam bentuk pakan, sehingga saat dimakan ikan uji, pakan tersebut mudah dan lebih cepat dicerna ikan.

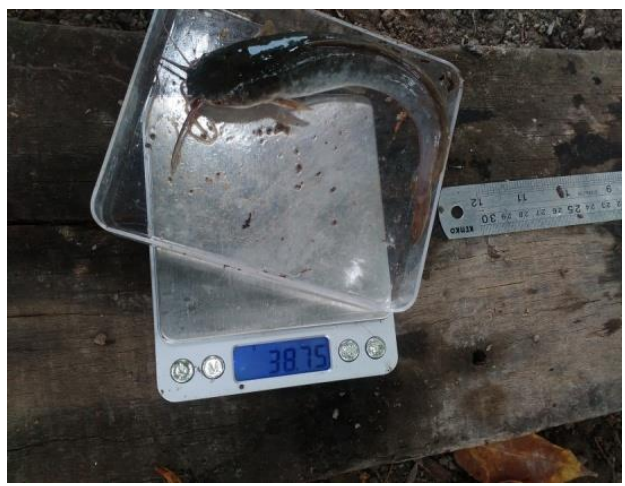

Gambar 2. Penimbangan bobot ikan lele

Tabel 1. Data pertumbuhan panjang mutlak dan pertumbuhan bobot mutlak ikan lele sangkuriang

\begin{tabular}{lllllll}
\hline Wadah Pemeliharaaan & $\mathrm{L}_{0}(\mathrm{~cm})$ & $\mathrm{L}_{\mathrm{t}}(\mathrm{cm})$ & $\mathrm{W}_{0}(\mathrm{~g})$ & $\mathrm{W}_{\mathrm{t}}(\mathrm{g})$ & $\Delta \mathrm{L}(\mathrm{cm})$ & $\Delta \mathrm{W}(\mathrm{g})$ \\
\hline Wadah I (Probiotik) & 13,90 & 17,41 & 20,11 & 37,26 & 3,51 & 17,15 \\
Wadah II (Non Probiotik) & 13,90 & 16,36 & 20,63 & 32,66 & 2,46 & 12,03 \\
\hline
\end{tabular}

Keterangan:

$\mathrm{L}_{0}=$ Panjang awal; $\mathrm{L}_{\mathrm{t}}=$ Panjang akhir; $\mathrm{W}_{0}=$ Bobot awal; $\mathrm{W}_{\mathrm{t}}=$ Bobot akhir

$\Delta \mathrm{L}=$ Pertumbuhan panjang mutlak; $\Delta \mathrm{W}=$ Pertumbuhan bobot mutlak

\section{Kelangsungan Hidup}

Berdasarkan Tabel 2 didapat hasil kelangsungan hidup ikan lele sangkuriang yang dipelihara dengan penggunaan probiotik (wadah I) pada budidaya yaitu sebesar $100 \%$ begitupun juga dengan hasil dari pemeliharaan yang tidak menggunakan probiotik (wadah II) sebesar $100 \%$. Benih ikan lele sangkuriang dipelihara dalam wadah drum plastik yang berukuran 110x75x64 cm. Menurut (Effendi et al., 2006) kelangsungan hidup adalah perbandingan jumlah ikan yang hidup hingga akhir pemeliharaan dengan jumlah ikan pada awal pemeliharaan. Selanjutnya, pemberian probiotik akan mempengaruhi peningkatan total leukosit yang mengindikasikan adanya respon perlawanan tubuh terhadap antugen penyebab penyakit (Setiawati et al., 2013).

Menurut (Kordi, 2009), ikan lele dikenal sebagai ikan yang sangat tahan terhadap perubahan lingkungan hidup dan memiliki kemampuan adaptasi yang baik terhadap berbagai jenis air.

\section{Kualitas Air}

Berdasarkan data hasil kualitas air selama penelitian (Tabel 3) yang telah dilakukan terdapat beberapa paramater kualitas air yang masih dapat ditolerir ikan yang diindikasikan dengan kelangsungan hidup ikan yang tinggi, terdapat parameter kualitas air yang dikatakan cukup mendukung untuk pemeliharaan ikan. Seperti suhu perairan dari awal sampai akhir berkisar antara $28-29^{\circ} \mathrm{C}$, Nilai suhu air ini masih berada dalam kisaran yang toleransi untuk media pemeliharaan ikan lele. Hal ini sesuai dengan (SNI, 2015), kisaran optimum untuk pemeliharaan ikan lele yaitu $25-30{ }^{\circ} \mathrm{C}$. Selama pemeliharaan didapatkan nilai kisaran $\mathrm{pH}$ yaitu berkisar 6,48-7,31, nilai ini masih tergolong dalam kisaran optimum. Hal ini sesuai dengan (SNI, 2015) nilai optimum $\mathrm{pH}$ untuk pemeliharaan ikan lele yaitu 6,5-8,5.

Pada kisaran tersebut ikan lele masih dapat hidup. Sedangkan pada nilai $\mathrm{pH}$ dibawah 4,5 air akan bersifat racun (Tancung, 2010). 
Efek langsung dari $\mathrm{pH}$ rendah dan $\mathrm{pH}$ yang terlalu tinggi adalah berupa kerusakan sel epitel, baik kulit maupun insang, hal ini akan mengganggu proses penyerapan oksigen terutama bagi ikan yang bernafas dengan menggunakan insang (Supian, 2012).

Tabel 2. Kelangsungan hidup ikan lele sangkuriang selama penelitian

\begin{tabular}{|c|c|c|c|c|c|}
\hline Wadah Pemeliharaan & $\mathrm{N}_{\mathrm{t}}($ ekor $)$ & $\mathrm{N}_{0}$ & kor) & Kelangsungan 1 & $\mathrm{p}(\%)$ \\
\hline Wadah I & 75 & & 75 & $100 \%$ & \\
\hline Wadah II & 75 & & 75 & $100 \%$ & \\
\hline $\begin{array}{l}\text { Keterangan: } \\
\mathrm{N}_{\mathrm{t}}=\text { Jumlah akhir per }\end{array}$ & aan; $\mathrm{N}_{0}=$ Jumlah & meliha & & & \\
\hline Tabel 3.Data kualitas & ma penelitian & & & & \\
\hline Waktu Pengukuran & $\begin{array}{c}\text { Kolam } \\
\text { Pemeliharaan }\end{array}$ & $\mathrm{pH}$ & Suhu $\left({ }^{0} \mathrm{C}\right)$ & $\begin{array}{l}\text { Oksigen } \\
\text { Terlarut } \\
(\mathrm{mg} / \mathrm{L})\end{array}$ & $\begin{array}{l}\text { Amonia } \\
(\mathrm{mg} / \mathrm{L})\end{array}$ \\
\hline Awal Pemeliharaan & Wadah I & 6,48 & 29,8 & 3,75 & 0,04 \\
\hline & Wadah II & 6,51 & 29,8 & 3,75 & 0,04 \\
\hline Akhir Pemeliharaan & Wadah I & 7,13 & 29,2 & 2,20 & 5,9 \\
\hline & Wadah II & 7,31 & 28,9 & 2,21 & 5,8 \\
\hline
\end{tabular}

Nilai oksigen terlarut yang didapat berada di bawah kisaran yang ideal yakni 3,75 mg/L (Wadah I) dan 2,20-2,21 mg/L (Wadah II). Kisaran optimum oksigen terlarut untuk ikan lele menurut (SNI, 2015) yaitu $>4 \mathrm{mg} / \mathrm{L}$. Hasil pengamatan nilai oksigen terlarut tergolong masih dalam kisaran normal untuk pemeliharaan ikan lele, karena ikan lele memiliki alat pernapasan tambahan dan dapat langsung mengambil oksigen di udara. Menurut (Sucipto et al., 2005), mengatakan bahwa kandungan oksigen terlarut dalam air sebaiknya dijaga diatas $5 \mathrm{mg} / \mathrm{L}$ untuk meningkatkan produktivitas ikan. Kandungan oksigen dibawah $1 \mathrm{mg} / \mathrm{L}$ dapat menyebabkan penurunan laju pertumbuhan ikan. Ikan lele dapat hidup dalam perairan kandungan oksigen berkisar antara $>3 \mathrm{mg} / \mathrm{L}$ (Kholish. 2009).

Selanjutnya, Ikan lele dapat hidup diperairan yang berlumpur karena memiliki alat bantu pernapasan yang terletak diatas rongga insang (arborescent) sehingga mampu mengambil oksigen langsung dari udara. Kualitas air yang baik untuk pertumbuhan ikan lele yaitu kandungan oksigen terlarut didalam air sebesar $3 \mathrm{mg} / \mathrm{L}$, suhu berkisar $20-32{ }^{\circ} \mathrm{C}$ dan $\mathrm{pH}$ berkisar 6,58 (Saparinto, 2014).
Adapun hasil pengukuran amonia di akhir pemeliharaan tidak sesuai dengan kisaran yang ideal yakni $0,04 \mathrm{mg} / \mathrm{L}$ (wadah I) dan $5,9 \mathrm{mg} / \mathrm{L}$ (wadah II). Hal ini dikarenakan pada (Wadah II) tidak terdapat probiotik. Kandungan amonia selama pemeliharaan masih dalam kisaran optimum. Tingginya kandungan amonia dalam media pemeliharaan ikan lele dikarenakan adanya sisa-sisa pakan yang tidak termakan dan sisa-sisa akibat metabolisme ikan yang mengendap di dasar media pemeliharaan. Nilai kisaran amonia dari hasil pengamatan ini masih memenuhi kisaran yang layak untuk pemeliharaan ikan lele sangkuriang yaitu kurang dari $1 \mathrm{mg} / \mathrm{L}$. Secara keseluruhan dari hasil pengamatan parameter kualitas air selama pemeliharaan 30 hari mampu mendukung pertumbuhan ikan lele sangkuriang dengan tingkat kelangsungan hidup ikan lele sangkuriang $100 \%$.

\section{KESIMPULAN}

Pemeliharaan ikan lele sangkuriang (Clarias sp.) dengan penggunaan probiotik mampu memberikan hasil yang baik dengan pertumbuhan panjang mutlak sebesar 3,51 cm dan bobot mutlak sebesar 17,15 g, serta kelangsungan hidup yang dihasilkan 
sebesar $100 \%$. Selanjutnya, penggunaan probiotik dapat diaplikasikan pada melalui wadah pemeliharaan kolam terpal dan juga melalui drum plastik. Salah satu tujuan penggunaan probiotik dapat membantu biodegradasi. Sehingga diharapkan penggunaan probiotik dapat mengurangi pergantian air dengan penggunaan kembali air bekas budidaya.

\section{DAFTAR PUSTAKA}

SNI. 2015. Identifikasi bakteri aeromonas hydrophila pada ikan. SNI: 7303.1.2015: $18 \mathrm{hlm}$.

Ahmadi H, Iskandar KN. 2012. Pemberian probiotik dalam pakan terhadap pertumbuhan lele sangkuriang (Clarias gariepinus) pada pendederan II. $J$. Perikanan dan Kelautan. 3(4): 99-107.

Effendi IH, Bugri J, Widanarni. 2006. Pengaruh padat penebaran terhadap kelangsungan hidup dan pertumbuhan benih ikan gurami (Osphronemus gouramy lac) ukuran $2 \mathrm{~cm}$. Jurnal Akuakultur Indonesia. 5(2): 127-135.

Effendie M. 2002. Biologi Perikanan edisi ke -2 (edisi revisi) Yogyakarta, Yayasan Pustaka Nusantara.

Esriyani A. 2013. Pengaruh penambahan larutan kunyit (Curcuma longa) pada Pakan terhadap pertumbuhan ikan lele dumbo (Clarias Gariepinus). Skripsi, PGRI Semarang.

Irianto A. 2007. Potensi Mikroorganisma: di atas langit ada langit. ringkasan orasi ilmiah di Fakultas Biologi, Universitas Jenderal Sudirman.

Kholish M. 2009. Panduan lengkap agribisnis lele. Jakarta, Penebar Swadaya.

Kordi GM. 2009. Budidaya Perairan Buku Kedua. Bandung, PT. Citra Aditya Bakti. Mudjiman A. 2009. Makanan Ikan. Jakarta, Penebar Swadaya.

Perikanan KK. 2016. Laporan Kinerja (LKj) Direktorat Jenderal Perikanan
Budidaya Triwulan III Tahun 2016. Jakarta Sekretariat Negara.

Pertiwi D. 2014. Aplikasi effective microorganism 10 (EM10) untuk pertumbuhan ikan lele sangkuriang (Clarias gariepinus var. sangkuriang) di dalam kolam budidaya lele Jombang Tanggerang. Skripsi, Universitas Syarif Hidayatullah.

Rosalina D. 2014. Analisis kelayakan usaha budidaya ikan lele di kolam terpal di Desa Namang Kabupaten Bangka Tengah. Maspari Journal. 6(11): 20-24.

Sahwan F. 2004. Pakan ikan dan udang: formulasi, pembuatan, analisa, ekonomi: jakarta.

Saparinto C. 2014. Bisnis Ikan Konsumsi di Lahan Sempit. Jakarta, Penebar Swadaya.

Setiawati JA, Tarsim YT, Adiputra, Hudaidah S. 2013. Pengaruh penambahan probiotik pada pakandengan dosis berbeda terhadap pertumbuhan, kelulus hidupan, efisiensi pakan dan retensi protein ikan patin (Pangasius Hypophthalamus). E-Jurnal Rekayasa dan Teknologi Budidaya Perairan. 1(2): 151-162.

Sucipto A, Prihartono RE. 2005. Pembesaran nila merah bangkok. Jakarta, Penebar Swadaya.

Sunarma A. 2004. Peningkatan produktifitas usaha lele sangkuriang (Clarias sp.). Makalah disampaikan pada Temu Unit Pelaksana Teknis (UPT) dan Temu Usaha Direktorat Jenderal Perikanan Budidaya, . D. K.d. perikanan. Bandung: $13 \mathrm{hlm}$.

Supian E. 2012. Penaggulangan hama dan penyakit pada ikan. Yogyakarta, Pustaka Baru.

Tancung GHKKdAB. 2010. Pengelolaan kualitas air dalam budi daya perairan. Jakarta, Rineka Cipta.

Widodo, Handajani. 2010. Nutrisi Ikan Malang, UMM Press. 